\title{
Histological Analysis of Dentition in Rockshelter Burials from Two Sites in Central Belize
}

\author{
Amy R. Michael ${ }^{1 *}$ \\ ${ }^{1}$ Department of Anthropology, Michigan State University, East Lansing, MI 48824
}

Keywords: histology, Wilson bands, health, bioarchaeology

ABSTRACT Objectives: Investigations of dental health in the Maya region have frequently focused on individuals buried at urban sites rather than in peripheral or intermediary zones. This study presents a dental analysis of a different type of mortuary sample, those persons buried in two non-elite peripheral rockshelters, in Central Belize using a combined dental micro- and macrodefect approach to interpret health experience.

Materials and Methods: A total of 22 teeth (permanent mandibular canines, and mandibular and maxillary third molars) from the two sites were assessed for dental caries, enamel hypoplasias, and Wilson bands. The maximum and minimum ages of microdefect formation for each tooth was calculated.

Results: Carious lesions were infrequently represented in the sample, while linear enamel hypoplasias were expressed in less than half the sample. Wilson bands, conversely, were present in nearly every tooth indicating that the rockshelter populations experienced more acute stress. Individuals interred at Caves Branch Rockshelter were affected earlier in life based on analysis of mandibular canines.

Conclusion: Non-elites buried in rockshelters in Central Belize had similar dental health experiences when compared with individuals buried at elite centers. At least in terms of oral health, peripheral communities in this area were not adversely affected by their distance from urban core sites

The Classic Period Maya (A.D. 250-900) was characterized by social stratification, emergence and expansion of elite classes, and integration of large urban centers (Cucina and Tiesler, 2003). During this period, the Maya incorporated multiple types of burial sites into their mortuary program across the ancient landscape. Traditionally, archaeologists have focused on the excavation of elite structures and tombs in the Maya area, so comparatively little research has been conducted on the bioarchaeological analysis of non-elite Maya burials from mortuary sites outside of civic-ceremonial centers. This study analyzed the dental remains of non-elite individuals distinguished in death by placement in two peripheral locations, Sapodilla (SDR) and Caves Branch (CBR) rockshelters, in Central Belize. Three indicators of stress (dental caries, linear enamel hypoplasia, and Wilson bands) were collected and estimations of age at defect formation were calculated to determine if these peripheral non-elite groups exhibited stress indicators in frequencies comparable to elite groups in the area.

This paper is one of the winners of the Albert A. Dahlberg Prize awarded at the Annual meeting of the American Association of Physical Anthropologists in 2016.
This study makes two original contributions: 1) the analysis of an understudied Maya mortuary sample using a method (dental histology) that is not widely applied in the regional bioarchaeology literature; and 2) the assignment of age at defect estimation to better interpret episodic health stress events during life. Using these data, rockshelter burials can be compared to two other main mortuary site types in the area, caves and surface sites, to better understand Maya mortuary behavior. Investigations of rockshelter burials, especially those of the highly socially stratified Classic Period, will help to close the gap between the much-studied elite class and those many communities that existed independently or semi-independently from urban site cores. Enamel defects can be seen macroscopically on the enamel crown as hypoplasias, taking furrow or pit forms. Microscopically, the defects present as Wilson bands, which are visualized as areas of disrupted ameloblast activity when the enamel is viewed in cross-

${ }^{*}$ Correspondence to:

Amy Michael

Department of Anthropology, Michigan State University, East Lansing, MI 48824, e-mail: michae76@msu.edu 
section. Hypoplasias, observed externally, and Wilson bands, viewed internally, are indelible markers that indicate a generalized systemic response to stress. The etiology of both defect types is not conclusively understood (Hillson 2014), but a combined study of hypoplasias, carious lesions, and Wilson bands allows for more nuanced conclusions about health experience to be drawn from a particular sample. If only macroscopic indicators of health stress were observed, the burial populations may appear to have had a more positive health experience than was their reality. However, by analyzing the teeth for three defect types, it is possible to observe more defects at more age ranges, resulting in a more complete picture of episodic health stress in the individual.

Health experience has historically been measured in human skeletal remains as a physiological disruption resulting in some kind of osteological or dental manifestation of pathology. The physical embodiment of poor health has often been read in the assessment of dental pathology in particular, but a conflation of "health" and "stress" is not intended in this study, but the limitations of interpreting dental pathological conditions are acknowledged here. Recently, bioarchaeologists have made increasing efforts to critically evaluate health studies and stress markers, drawing more conclusions from the incorporation of theoretical models and data from fields of epidemiology, primatology, and clinical biology (Gowland 2015; Temple and Goodman 2014). For this sample, dental pathological conditions are still used as a proxy of health experience, but the complexities of individual well-being cannot possibly be totalized by observable defects. It is recognized that intangible processes and states of emotional being that leave no inscription on the archaeological record and are difficult to measure on the physical body contribute to overall health experience. To mitigate this fact, multiple dental pathological conditions are combined to determine the extent of expression between and among individuals at these rockshelter sites. These baseline data then allow for the proposition of larger anthropological questions of health experience as more archaeological data becomes available.

Specifically, five research questions were asked of this sample: 1) What is the age at defect formation range and mean age at defect formation for each tooth?; 2) How many Wilson bands were observed for each tooth?; 3) How many enamel hypoplasias were observed for each tooth?; 4) How many carious lesions were observed for each tooth?; and 5) What is the relationship, if any, between dental macro- and microdefects?

\section{BIOCULTURAL CONTEXT}

The assessment of rockshelter burials in the Maya region is still a relatively new endeavor and certainly part of an ongoing focus on analyzing non-elite burial populations (Dunham et al., 1998; Glassman and Villarejo, 2005; Goldstein and Prufer, 1999; Saul et al., 2005; Scott and Brady, 2005; Wrobel, 2008). The data presented in this paper contribute to the continuing collection of information about the lifeways and social identities of individuals from rural communities. Frequently, archaeologists have posited that cave access was governed in part by social status, whereby elites controlled large darkzone caves for the purposes of ritual activity while non-elite activity was relegated to the smaller, less visually impressive caves and rockshelters (Awe et al., 1998; Graham, 1980; Peterson, 2006; Reents, 1980; Wrobel et al., 2009). The debates over cave and rockshelter use continue in the literature, so the biological data presented here can usefully augment current and future archaeological data collected from these mortuary spaces.

Sapodilla Rockshelter (SDR) is situated near a small tributary of the Caves Branch River system within the northern portion of the Caves Branch River Valley in Central Belize. Over the course of two field seasons of the Central Belize Archaeological Survey (CBAS), the presence of $40-50$ primary burials, commingled human and faunal bones, ceramics, and lithics was confirmed (Michael and Burbank 2013). Ceramic types recovered at SDR reveal that the use of the site was predominantly limited to the Protoclassic and Early Classic periods (Michael and Burbank 2013). The mortuary patterns and artifact assemblages appear similar to another peripheral site, Caves Branch Rockshelter (CBR), located approximately 1 kilometer away (Glassman and Bonor, 2005; Wrobel, 2008). Some evidence for post-mortem secondary manipulation of remains was noted, as one nearly complete burial was absent the cranium yet the mandible was present, and two isolated skulls were discovered. Burials at SDR were easily individualized since interments were either undisturbed or only slightly commingled. Teeth were mostly retained in the skull or were scattered in close proximity to the body.

Caves Branch Rockshelter, situated in the Caves Branch River Valley east of the present-day Belizean capital of Belmopan, was first excavated by Juan Luis Bonor in the mid-1990s after a number of looting events (Glassman and Bonor, 2005). This salvage operation yielded 32 primary burials, but dense commingling contributed to the countless bone fragments mixed throughout the burial matrix. Following Bonor's work, Wrobel continued excavations at CBR during 2005-2007 with the Belize Valley Archaeological Reconnaissance (BVAR) Project and again in 2015 with CBAS. All CBR excavations demonstrated that the site was unrestricted by sex or age, further sug- 
gesting that the mortuary regulations that governed interment in rockshelters were inclusive. Attendant grave artifacts were sparse and utilitarian reflecting use consistent with a rural farming population

(Wrobel, 2008). Based on excavations to date, an estimated 400-500 individuals may be interred at the site (Wrobel et al., 2009). The ceramic assemblage spanned a large period of time from the Formative Period to the Terminal Classic (Bonor, 2002; Wrobel et al., 2009; Wrobel, 2008). However, the diagnostic ceramics interred as grave goods were largely from the Late Preclassic, indicating that the most intensive use of the rockshelter likely occurred during this period (Wrobel, 2008a). Two burials were subjected to AMS dating and returned Late Preclassic and Late Classic dates suggesting that use may not have been punctuated, but rather persistent (to varying degrees) through time. During the Late Preclassic, there is no evidence for urban centers in the valley, further underscoring the use of the rockshelter by agrarian communities (Wrobel, 2008a).

\section{MATERIALS AND METHODS}

For this study, two tooth classes (permanent and deciduous) mandibular canines, and maxillary and mandibular third molars were selected for analysis following Danforth's (1989) study on pre-Hispanic Maya burials (Tables 1 and 2). Left teeth were preferentially selected, but when not available the antimere was collected for analysis. Due to similarity in enamel formation rates, both the mandibular and maxillary third molars were selected when either was present.

Prior to thin sectioning for microscopic analysis, data were collected on dental caries and enamel hypoplasias following Buikstra and Ubelaker (1994). Enamel hypoplasias were scored using a combination 3 . of the "thumbnail" test and taking an impression in putty. The putty records both slighter expressions of horizontal grooves, as well as pit defects that may not be as immediately visible during the thumbnail test. Color and width of the hypoplasias were not recorded, as these data have not been demonstrated to pro-

\section{TABLE 1. Distribution of teeth in the sample from CBR}

\begin{tabular}{lcc}
\hline Tooth Type & Right & Left \\
\hline Mandibular canine & 4 & 6 \\
Maxillary third molar & 0 & 0 \\
Mandibular third molar & 0 & 0 \\
Deciduous mandibular canine & 3 & 1 \\
\hline TOTAL & 7 & 7 \\
\hline
\end{tabular}

TABLE 2. Distribution of teeth in the sample from $S D R$

\begin{tabular}{lcc}
\hline Tooth Type & Right & Left \\
\hline Mandibular canine & 5 & 1 \\
Maxillary third molar & 1 & 0 \\
Mandibular third molar & 0 & 1 \\
Deciduous mandibular canine & 0 & 0 \\
\hline TOTAL & 6 & 2 \\
\hline
\end{tabular}

vide any useful biological information (Buikstra and Ubelaker 1994). Fitzgerald and Saunders (2005) also stated that variables other than defect presence do not factor into the threshold level or denote severity of the defect.

To identify Wilson bands, the parameters advocated by Hillson (2014:174-175), which were adapted from Rose et al. (1978:513), and Goodman and Rose (1990:93) were first considered as the standard observation and identification method for this project. Because there is largely no congruent definition in the literature as every author chooses biological criteria and visual representation to prioritize, it was determined that enamel disruptions would be recorded as Wilson bands if two of the three criteria were met, following a recent Wilson band study done by Reeves (2013:42):

1. the stria appears darker and wider than surrounding striae, extending clearly from the dento -enamel junction to the enamel surface

2. the stria exhibits rod disorganization on examination at $1000 x$ magnification

3. the stria has a corresponding darkened stria in the lingual enamel

Other criteria could potentially be added to this list, but the general presentation of disorganized enamel prisms, darkened striae, and bilateral expression are repeated most frequently throughout the literature.

Each sample was impregnated with a resin/ hardener mixture and cut in midline. One thin section of approximately $80-100 \mu \mathrm{m}$ (Fitzgerald and Rose, 2000; Hillson, 2014) was created for examination of the internal surface. Thin sections were analyzed using a standard light transmitted binocular LED digital compound microscope with 3D stage and 9MP camera attachment from United Scope. The AmScope 3.7 software included with the microscope was used to image the samples. The digital camera attachment provided a live feed to the computer, as well as an image capture feature. Thin sections were first magnified at $1000 x$ to identify defects, then they were observed and photographed between 400 - 
$600 x$.

Following Cook (1981), Danforth (1989) developed a population-specific age-at-defect formation schedule for Maya dental remains (deciduous canines, permanent canines, third molars). Danforth (pers. comm. 2011) stated that it would be reasonable to use these standards for the rockshelter samples. Measurements of the location of the Wilson bands were taken along the DEJ with the CEJ acting at the zero point. For instance, if a Wilson band was recorded at $2.25 \mathrm{~mm}$, that means that the defect began $2.25 \mathrm{~mm}$ from the CEJ. These measurements were matched to the ap- propriate increment for each tooth class. For example, if a defect in a third molar of a female was noted at $3.1 \mathrm{~mm}$ from the CEJ, the associated increment would be in Danforth's DEJ zone 5 and the associated age range would be 10.7 - 11.3 years; (Table 3; see Tables 4 and 5 for other tooth classes). In instances where the sex of the individual was estimated, then the male or female age range was used. The majority of the individuals from CBR and SDR do not have sex estimations, and the combined age ranges were employed.

TABLE 3. Age at development for mandibular third molars* (adapted from Danforth 1989)

\begin{tabular}{ccccc}
\hline DEJ Zone & $\begin{array}{l}\text { AmScope Measurement } \\
\text { (mm from CEJ) }\end{array}$ & $\begin{array}{l}\text { Age in Years } \\
\text { (Males) }\end{array}$ & $\begin{array}{l}\text { Age in Years } \\
\text { (Females) }\end{array}$ & $\begin{array}{c}\text { Age in Years } \\
\text { (Combined Sexes) }\end{array}$ \\
\hline 1 & $6.01-7.0$ & $9.0-9.6$ & $9.1-9.6$ & $9.0-9.6$ \\
2 & $5.01-6.0$ & $9.6-10.3$ & $9.6-10.2$ & $9.6-10.2$ \\
3 & $4.01-5.0$ & $10.3-10.9$ & $10.2-10.7$ & $10.2-10.8$ \\
4 & $3.01-4.0$ & $10.9-11.6$ & $10.7-11.3$ & $10.9-11.4$ \\
5 & $2.01-3.0$ & $11.6-12.3$ & $11.3-11.8$ & $11.4-12.0$ \\
6 & $1.01-2.0$ & $12.3-13.0$ & $11.8-12.3$ & $12.0-12.7$ \\
7 & $0.0-1.0$ & $13.0-13.6$ & & $13.0-13.6$
\end{tabular}

*The same chart was used for maxillary third molars based on the very similar development times (Logan and Kronfield 1933)

TABLE 4. Age at development for mandibular canines (adapted from Danforth 1989)

\begin{tabular}{|c|c|c|c|c|}
\hline DEJ Zone & $\begin{array}{l}\text { AmScope Measurement } \\
\text { (mm from CEJ) }\end{array}$ & $\begin{array}{l}\text { Age in Years } \\
\text { (Males) }\end{array}$ & $\begin{array}{l}\text { Age in Years } \\
\text { (Females) }\end{array}$ & $\begin{array}{l}\text { Age in Years } \\
\text { (Combined Sexes) }\end{array}$ \\
\hline 1 & $11.01-12.0$ & $0.7-1.1$ & $0.5-0.9$ & $0.6-1.0$ \\
\hline 2 & $10.01-11.0$ & $1.1-1.5$ & $0.9-1.3$ & $1.0-1.4$ \\
\hline 3 & $9.01-10.0$ & $1.5-1.8$ & $1.3-1.7$ & $1.4-1.8$ \\
\hline 4 & $8.01-9.0$ & $1.8-2.2$ & $1.7-2.1$ & $1.8-2.1$ \\
\hline 5 & $7.01-8.0$ & $2.2-2.6$ & $2.1-2.5$ & $2.1-2.5$ \\
\hline 6 & $6.01-7.0$ & $2.6-3.0$ & $2.5-2.9$ & $2.5-2.9$ \\
\hline 7 & $5.01-6.0$ & $3.0-3.4$ & $2.9-3.3$ & $2.9-3.3$ \\
\hline 8 & $4.01-5.0$ & $3.4-3.8$ & $3.3-3.7$ & $3.3-3.7$ \\
\hline 9 & $3.01-4.0$ & $3.8-4.1$ & $3.7-4.0$ & $3.7-4.1$ \\
\hline 10 & $2.01-3.0$ & $4.1-4.5$ & $4.0-4.4$ & $4.1-4.5$ \\
\hline 11 & $1.01-2.0$ & $4.5-4.9$ & $4.4-4.8$ & $4.5-4.9$ \\
\hline 12 & $0.0-1.0$ & $4.9-5.3$ & & $4.9-5.3$ \\
\hline
\end{tabular}


TABLE 5. Age at development for deciduous mandibular canines (adapted from Danforth 1989)

\begin{tabular}{ccc}
\hline $\begin{array}{l}\text { DEJ } \\
\text { Zone }\end{array}$ & $\begin{array}{c}\text { AmScope } \\
\text { Measurement } \\
\text { (mm from CEJ) }\end{array}$ & $\begin{array}{c}\text { Age in Months } \\
\text { (Combined Sexes) }\end{array}$ \\
\hline 1 & $7.01-8.0$ & $5-6$ (in utero) \\
2 & $6.01-7.0$ & $7-8$ (in utero) \\
3 & $5.01-6.0$ & 9 (in utero) -1 (post \\
& & - birth) \\
4 & $4.01-5.0$ & $2-3$ \\
5 & $3.01-4.0$ & $4-5$ \\
6 & $2.01-3.0$ & $6-7$ \\
7 & $1.01-2.0$ & $8-9$ \\
8 & $0.0-1.0$ & $10-11$ \\
\hline
\end{tabular}

RESULTS

Table 6 summarizes the data collected for the SDR sample. Six individuals were represented in the sample, but only two of these burials retained more than one desired tooth. Of the eight teeth available, none exhibited carious lesions, three showed linear enamel hypoplasias, and all but one tooth had Wilson bands. The number of Wilson bands in each tooth class and the average age point estimate for each tooth class is summarized in Table 7. With one exception, the teeth were all mandibular canines with Wilson band formation occurring as early as 2.1 years (Burial 17) and as late as 4.9 years (Burials 9 and 13). The number of Wilson bands per tooth was five or under for six of the seven teeth with microdefects. Burial 17, exhibiting 12 Wilson bands, was an outlier. Interestingly, Burial 17 was the only individual in this sample interred in the liminal zone between the rockshelter overhang (where most skeletal remains were found) and the small dark zone cave. This burial was also distinguished by the hundreds of shell tinklers forming a belt and bracelet on the body; no other burial at SDR was as decorated.

Table 8 summarizes the data collected for CBR. Of the fourteen teeth available, all were from different individuals. Only two of these teeth exhibited carious lesions, while six teeth demonstrated at least one linear enamel hypoplasia. Every tooth in the sample expressed at least one Wilson band. The earliest age of Wilson band formation in the deciduous teeth occurred at $0.33-0.42$ years (Burial 19) and the latest

TABLE 6. Summary of data collected for SDR

\begin{tabular}{lccccccc}
\hline Burial & Tooth & $\begin{array}{c}\text { No. of } \\
\text { Caries }\end{array}$ & $\begin{array}{l}\text { No. of } \\
\text { Hypplasias }\end{array}$ & $\begin{array}{l}\text { No. of Wil- } \\
\text { son bands }\end{array}$ & Min. Age & Max. Age & $\begin{array}{l}\text { Point Esti- } \\
\text { mate Age }\end{array}$ \\
\hline Burial 6 & $\mathrm{RC}_{-}$ & 0 & 2 & 4 & 3.7 & 4.5 & 4.1 \\
Burial 7 & $\mathrm{RC}_{-}$ & 0 & 0 & 5 & 2.5 & 3.7 & 3.1 \\
Burial 9 & $\mathrm{RC}-$ & 0 & 0 & 4 & 3.3 & 4.9 & 4.1 \\
Burial 10 & $\mathrm{RM}_{-}^{3}$ & 0 & 0 & 0 & $\mathrm{~N} / \mathrm{A}$ & $\mathrm{N} / \mathrm{A}$ & $\mathrm{N} / \mathrm{A}$ \\
Burial 10 & $\mathrm{RC}_{-}$ & 0 & 1 & 2 & 3.3 & 4.1 & 3.7 \\
Burial 13 & $\mathrm{LM}_{3}$ & 0 & 0 & 3 & 11.4 & 12.0 & 11.7 \\
Burial 13 & $\mathrm{LC}_{-}$ & 0 & 2 & 4 & 2.5 & 4.9 & 3.7 \\
Burial 17 & $\mathrm{RC}_{-}$ & 0 & 0 & 12 & 2.1 & 4.1 & 3.1 \\
\hline
\end{tabular}

TABLE 7. Summary of SDR sample: Wilson bands and ages

\begin{tabular}{lcc}
\hline Tooth Class & $\begin{array}{l}\text { Number of Wilson Bands } \\
\text { in Entire Tooth Class }\end{array}$ & $\begin{array}{l}\text { Point Estimate of Average } \\
\text { Affected Age }\end{array}$ \\
\hline Mandibular canine $(\mathrm{n}=6)$ & 31 & 3.63 \\
Third Molar (mandibular and maxillary) $(\mathrm{n}=2)$ & 3 & 11.7 \\
Deciduous mandibular canine $(\mathrm{n}=0)$ & $\mathrm{N} / \mathrm{A}$ & $\mathrm{N} / \mathrm{A}$ \\
\hline
\end{tabular}


TABLE 8. Summary of data collected for CBR

\begin{tabular}{llcccccc}
\hline Burial & Tooth & $\begin{array}{c}\text { No. of } \\
\text { Caries }\end{array}$ & $\begin{array}{c}\text { No. of } \\
\text { Hypoplasias }\end{array}$ & $\begin{array}{c}\text { No. of Wil- } \\
\text { son bands }\end{array}$ & Min. Age & Max. Age & $\begin{array}{c}\text { Point Estimate } \\
\text { Age }\end{array}$ \\
\hline Burial 2 & LC & 0 & 2 & 1 & 2.5 & 2.9 & 2.7 \\
Burial 9 & RC & 0 & 5 & 3 & 2.6 & 3.4 & 3.0 \\
Burial 10 & LC & 0 & 3 & 1 & 2.1 & 2.5 & 2.3 \\
Burial 11 & LC & 0 & 0 & 3 & 3.0 & 3.8 & 3.4 \\
Burial 19 & rc & 1 & 0 & 1 & 0.33 & 0.42 & 0.38 \\
Burial 23b & rc & 0 & 0 & 1 & 0.5 & 0.58 & 0.54 \\
Burial 36A & rc & 0 & 0 & 1 & 0.5 & 0.58 & 0.54 \\
Burial 38 & RC & 0 & 0 & 3 & 2.9 & 3.3 & 3.1 \\
Burial 46C/42 & LC_ & 0 & 1 & 9 & 1.8 & 4.5 & 3.15 \\
Burial 51 & RC & 0 & 2 & 7 & 1.3 & 4.0 & 2.65 \\
Burial 63 & LC & 0 & 0 & 3 & 2.9 & 3.3 & 3.1 \\
Burial 71 & lc & 0 & 0 & 3 & 0.5 & 0.75 & 0.63 \\
Burial 86 & RC & 0 & 1 & 7 & 2.2 & 3.8 & 3.0 \\
Burial 246 & LC & 1 & 0 & 6 & 2.0 & 4.4 & 3.2 \\
\hline
\end{tabular}

age at defect formation in the deciduous teeth occurred at $0.5-0.75$ years (Burial 71). For the permanent teeth, the earliest age at defect formation was 1.3 years (Burial 51) and the latest was 4.5 years (Burial 46C/42). Table 9 summarizes the number of Wilson bands in each tooth class and the average age at defect formation for each tooth class.

TABLE 9. Summary of CBR sample: Wilson bands and ages

\begin{tabular}{lccc}
\hline Tooth Class & $\mathrm{N}$ & $\begin{array}{c}\text { Number of } \\
\text { Wilson Bands } \\
\text { in Entire } \\
\text { Tooth Class }\end{array}$ & $\begin{array}{c}\text { Point Esti- } \\
\text { mate of Av- } \\
\text { erage Affect- } \\
\text { ed Age }\end{array}$ \\
\hline $\begin{array}{l}\text { Mandibular } \\
\text { canine }\end{array}$ & 10 & 43 & 2.96 \\
$\begin{array}{l}\text { Third Molar } \\
\text { (mandibular } \\
\text { and maxil- }\end{array}$ & 0 & N/A & N/A \\
$\begin{array}{l}\text { lary) } \\
\begin{array}{l}\text { Deciduous } \\
\text { mandibular } \\
\text { canine }\end{array}\end{array}$ & 4 & 6 & \\
\hline
\end{tabular}

\section{DISCUSSION AND CONCLUSIONS}

The rockshelter burials investigated in this paper provide baseline data for understanding rural burial populations in Central Belize. Unfortunately, the samples are too small to present statistically significant results, but the descriptive data do demonstrate some patterns. Carious lesions were rarely present at either site, a trend that follows other sites in Central Belize (Slon and Michael, 2013). Hypoplasias were always linear in formation, but at both sites the total frequency of hypoplastic defects was under $50 \%$ for the sample. Nearly all teeth expressed at least one Wilson band indicating that these defects, signaling more acute stress events (Wright, 1990), were the norm in these rockshelter burials. The etiology of these microdefects is still not conclusively known, but the disruption of the enamel prisms can, at minimum, be understood to be reflective of some stress event. Of the 22 teeth in the sample, 12 exhibited Wilson bands without presentation of enamel hypoplasias demonstrating that the presence of one defect does not necessarily predict the presence of the other. In fact, the burial with the most microdefects (Burial 17 from SDR) showed no linear enamel hypoplasias.

The average ages at defect formation for each tooth type demonstrate that individuals at CBR were affected by health stress somewhat earlier (2.96 years 
for the mandibular canine), while health stress occurred later at SDR (3.63 years for the mandibular canine). Deciduous canines, only present at CBR, expressed an average age at defect formation at 0.52 years. Third molars, only present at SDR, expressed an average age of defect formation at 11.7 years.

What can be gleaned from this project is that, largely, the individuals buried at these two rockshelter sites did not experience overwhelming dental health disturbances. These rural communities may once have been assumed to have suffered greater health disparities due to their lower social status, but that hypothesis is proven incorrect here. Previous bioarchaeological research has focused on health experience leading up to (or at the time of) "collapse" when the Maya were re-organizing their political alliances and social structure (Cucina and Tiesler, 2003, 2005; Danforth, 1989, 1997; Gerry, 1997; Storey, 1997; White et al., 2001; White, 1997, 2005; Wright, 1997; 2006), or during the Contact period when the Maya were introduced to new biological and social stresses brought on by the arrival of the Spanish (Danforth, 1989; Wright, 1990). Neither of these periods, in spite of extraordinary cultural change, has been shown to have a significant effect on the development of Wilson bands and/or enamel hypoplasias.

While this study does not focus on periods of social change, the similar results cautiously suggest that residence in peripheral communities (rather than urban centers) did not result in negative biological consequences. Non-elites living in rural settlements both adapted to and acted in concert with their surroundings, responding to both environmental and social pressures. The addition of more health data from rockshelter sites in Central Belize, as well as other Classic Period rockshelters throughout the country, are necessary to determine the extent to which residence in peripheral zones affected health experience. These data indicate that a binary model of health stress (e.g. elites did not suffer, while commoners suffered greatly) likely does not encapsulate the experience of the Classic Period Maya.

\section{ACKNOWLEDGEMENTS}

Dr. Gabriel Wrobel, Dr. Kip Andres, and Dr. Shawn Morton, of the Central Belize Archaeological Survey, allowed me to work on the CBAS project and collect these dental samples. Michigan State University Department of Anthropology and the Caves Research Foundation provided partial funding for sample preparation. the samples to be sent to Spectrum Petrographics. The Institute of Archaeology in Belize provided permission for the histological analysis of these samples.

\section{LITERATURE CITED}

Antonova, A. 2011. Growth, stress and mortality: application of dental histology to archaeological material from the Cis-Baikal Neolithic. MA thesis, University of Calgary.

Awe, J.J. 1998. The Western Belize Regional Cave Project: A Report of the 1997 Field Season. University of New Hampshire, Department of Anthropology.

Bonor, JL. 2002. Caves Branch Caves: Archaeological Field Report. Research Report submitted to the Foundation for the Advancement of Mesoamerican Studies, Crystal River.

Buikstra, J.E., Ubelaker, D.H. 1994. Standards for Data Collection from Human Skeletal Remains. Proceedings of a seminar at the Field Museum of Natural History, Vol. 68. Arkansas Archaeological Survey.

Cook, D.C. 1981. Mortality, age structure, and status in the interpretation of stress indicators in prehistoric skeletons: a dental example from the Lower Illinois River Valley. In: Chapman, R., Kinnes, I., Randsborg, K. (Eds.), The Archaeology of Death (pp. 133-144). London: Cambridge University Press.

Cucina, A., Tiesler, V. 2003. Dental caries and antemortem tooth loss in the northern Peten area, Mexico: a biocultural perspective on social status differences among the Classic Maya. Am J Phys Anthropol 122:1-10.

Danforth, M.E. 1989. A comparison of childhood health patterns in the Late Classic and Colonial Maya using enamel microdefects. PhD dissertation, Indiana University.

Danforth, M.E. 1997. Late Classic Maya health patterns: evidence from enamel microdefects. In: Whittington, S.L., Reed, D.M. (Eds.). Bones of the Maya (pp. 127-137). Washington DC: Smithsonian Institution Press.

Dunham, P.S., Buchanan, J.P., Meurer, W.P. 1998. The Maya Mountains Archaeological Project (MMAP): Report of the 1998 Field Season.

Fitzgerald, C.M., Rose, J.C. 2000. Reading between the lines: dental development and subadult age assessment using the microstructural growth markers of teeth. In: Katzenberg, M.A., Saunders, S.R. (Eds.) Biological Anthropology of the Human Skeleton (pp. 237-263). John Wiley and Sons.

Fitzgerald, C.M., Saunders, S.R. 2005. Test of histological methods of determining chronology of accentuated striae in deciduous teeth. Am J Phys Anthropol 127:277-290.

Gerry, J.P. 1997. Bone isotope ratios and their bearing on elite privilege among the Classic Maya. Geoarchaeology 12:41-69.

Glassman, D.M., Villarejo Bonor, J.L. 2005. Mortuary practices of the prehistoric Maya from Caves 
Branch Rockshelter, Belize. In: Prufer, K.M., Brady, J.E. (Eds.) Stone Houses and Earth Lords (pp. 285-296). Boulder: University Press of Colorado.

Goldstein, D.J., Prufer, K.M. 1999. Report on rockshelter excavations at Mayahek Cab Pek and Mohibal Kanchi, 1998 field season. In: Dunham, P.S. (Ed.) The Maya Mountains Archaeological Project (MMAP): 1997 and 1998 archaeological excavations in the Upper Bladen drainage.

Goodman, A.H., Rose, J.C. 1990. Assessment of systemic physiological perturbations from dental enamel hypoplasias and associated histological structures. Am J Phys Anthropol 33:59-110.

Gowland, R.L. 2015. Entangled lives: implications of the developmental origins of health and disease hypothesis for bioarchaeology and the life course. Am J Phys Anthropol 158:530-540.

Graham, E., McNatt, L., Gutehen, M.A. 1980. Excavations in Footprint Cave, Caves Branch, Belize. Journal of Field Archaeology 7.2:153-172.

Hillson, S., Antoine, D., Dean, M.C. 1999. A detailed developmental study of the defects of dental enamel in a group of post-medieval children from London. In: Mayhall, J.T., Heikkinen, T. (Eds.) Proceedings of the $11^{\text {th }}$ International Symposium of Dental Morphology, August 26-30, 1998 (pp. 102-111). Oulu, Finland: Oulu University Press.

Hillson, S. 2014. Tooth Development in Human Evolution and Bioarchaeology. Cambridge: Cambridge University Press.

Marks, M.K. 1993. Dental enamel microdefects as indicators of childhood morbidity among historic African Americans. PhD dissertation, The University of Tennessee.

Michael, A.R., Wrobel, G.D. 2011. A Dental Histological Analysis of Individuals Interred in a Variety of Cave and Rockshelter Contexts in the Caves Branch River Valley. Paper at Society for American Archaeology annual meetings, Sacramento, CA, March 30-April 3, 2011.

Michael, A.R., Burbank, J.A. 2013. Excavations at Sapodilla Rockshelter, Caves Branch River Valley. The Central Belize Archaeological Project: A Report of the 2011 Field Season. Belize Archaeologial Research and Education Foundation Occasional Report \#3. pp. 20-37.

Rose, J.C., Armelagos, G.J., Lallo, J.W. 1978. Histological enamel indicator of childhood stress in prehistoric skeletal samples. Am J Phys Anthropol 49:511-516.

Reents, D.J. 1980. The prehistoric pottery from Petroglyph Cave, Caves Branch River Valley, El Cayo District, Belize, Central America. Unpublished MA thesis, Department of Anthropology, Univer- sity of Texas, Austin.

Reeves, M.E. 2013. Profiling metabolic stress in medieval Denmark: an analysis of internal and external enamel defects. PhD dissertation, The University of North Carolina at Chapel Hill.

Saul, J.M., Prufer, K.M, Saul, F.P. 2005. Nearer to the Gods: rockshelter burials from the Ek Xux Valley, Belize. In: Prufer, K.M., Brady, J.E. (Eds.). Stone Houses and Earth Lords: Maya Religion in the Cave Context (pp. 297-322). Boulder, CO: University of Colorado Press.

Scott, A.M., Brady, J.E. 2005. Human remains in Lowland Maya caves: problems of interpretation. In: Prufer, K.M., Brady, J.E. (Eds.) Stone Houses and Earth Lords: Maya Religion in the Cave Context (pp. 263-284). Boulder, CO: University of Colorado Press.

Simpson, S.W. 1999. Reconstructing patterns of growth disruption from enamel microstructure. In: Hoppa, R.D., Fitzgerald, C.M. (Eds.) Human Growth in the Past: Studies from Bones and Teeth (pp. 241-263). Cambridge University Press.

Slon, B., Michael, A.R. 2013. Paper at the Chacmool Conference in Calgary, Alberta, Canada, November 7-9, 2013. An Analysis of Dental Defects in Cave and Rockshelter Populations, Central Belize.

Storey, R. 1997. Individual frailty, children of privilege, and stress in Late Classic Copan. In: Whittington, S.L., Reed, D.M. (Eds.) Bones of the Maya (pp. 116-126). Washington DC: Smithsonian Institution Press.

Temple, D.H., Goodman, A.H. 2014. Bioarchaeology has a "health" problem: conceptualizing "stress" and "health" in bioarchaeological research. Am J Phys Anthropol 155:186-191.

Thomson, C.C. 2011. Dental microstructures and maturation: a case study of stress during growth and development. MA thesis, Trent University.

White, C.D. 1997. Ancient diet at Lamanai and Pacbitun: implications for the ecological model of collapse. In: Whittington, S.L., Reed, D.M. (Eds.) Bones of the Maya (pp. 171-180). Washington DC: Smithsonian Institution Press.

White, C.D. (2005). Gendered food behaviour among the Maya: time, place, status, and ritual. Journal of Social Archaeology 5:356-382.

Witzel, C., Kierdorf, U., Schultz, M., Kierdorf, H. 2008. Insights from the inside: histological analysis of abnormal enamel microstructure associated with hypoplastic enamel defects in human teeth. Am J Phys Anthropol 136:400-414.

Wright, L.E. 1990. Stresses of conquest: a study of Wilson bands and enamel hypoplasias in the Maya of Lamanai, Belize. Am J Hum Biol 2:25-35. Wright, L.E. 1997. Intertooth patterns of hypoplasia 
expression: implications for childhood health in the Classic Maya collapse. Am J Phys Anthropol 102:233-247.

Wright, L.E. 2006. Diet, Health, and Status among the Pasion Maya: A Reappraisal of the Collapse.

Vanderbilt Institute of Mesoamerican Archaeology, Volume 2. Nashville, TN: Vanderbilt University Press.

Wrobel, G.D., Tyler, J., Hardy, J. 2007. Rockshelter excavations in the Caves Branch River Valley. Research Reports in Belizean Archaeology 4:187196.

Wrobel, G.D. 2008. Report on the Caves Branch Rockshelter excavations 2006 and 2007 field seasons. Belize Valley Reconnaissance Project field report. Wrobel, G.D., Jordan, J.M., Hardy, J. 2009. Social and political transformations in the Caves Branch River Valley: evidence from natural and constructed ritual environments. Research Reports in Belizean Archaeology 6:199-207. 